\title{
Karl Friedrich Burdach and his place in the history of neuroanatomy ${ }^{1}$
}

\author{
ALFRED MEYER ${ }^{2}$ \\ Professor Emeritus of Neuropathology, University of London
}

The name of Burdach is associated usually with Naturphilosophie which, during the closing decades of the 18th and in the early 19th century, flourished in Germany. It was inspired by the speculative - philosophies of Immanuel Kant's successors, and especially by Schelling, who regarded nature and mind as identical: to him nature was a preparatory stage (Vorstufe), in which mind could develop and unfold. Because they are essentially the same, all manifestations of nature and its ever more differentiated stages (mineral, plant, animal, man) could be deduced by logical operations of the human mind. Schelling, who had only inadequate knowledge of natural sciences and of medicine, thus opened the gates wide for speculation-a development which, before the middle of the 19th century, led to the early eclipse of the romantic philosophy of nature. Yet in its earlier phase, nature philosophy cast its spell over many scientists and medical men: Goethe was, perhaps, its most illustrious and Lorenz Oken, the biologist, its most fanatical adherent; but it influenced many other distinguished men (at least temporarily)-for example, Johann Christian Reil, Gottfried Reinhold Treviranus, Karl Gustav Carus, Johann Friedrich Blumenbach, and Ignaz Döllinger and Karl Ernst von Baer, the embryologists. ${ }^{3}$ Most of these workers accepted also vitalistic views as they had been developed earlier by Georg Ernst Stahl (1660-1734), and, later, by Théophile Bordeu (1722-1776).

Despite their adherence to nature philosophy, all these workers made notable contributions to their

\footnotetext{
${ }^{1}$ This paper is dedicated to Professor Willibald Scholz (München) a neuropathologist of world renown and a friend since the days of Walter Spielmeyer, in honour of his 80 th birthday. It is an amplified version of a contribution to the joint meeting of the British Society of Neuropathology and the Vereinigung Deutscher Neuropathologen und Neuroanatomen, at Oxford in July 1969. The two diagrams are identical with Figs. 21 and 24 of Historical Aspects of Cerebral Anatomy, now in process of publication. I wish to thank Oxford University Press for agreeing to their use in this paper.

2Address for reprints: 38 Wood Lane, Highgate, London N.6.

${ }^{3}$ As Singer (1959) pointed out, even Johannes Müller adhered for some time to the Goethe-Oken vertebral theory of the skull. Singer also stressed that Naturphilosophie was not confined to Germany. Etienne Geoffrey St. Hilaire in France, and Richard Owen in England carried deep marks of its influence. Likewise Franz Joseph Gall, who was born in Tiefenborn in Germany, was not free of its influence (Diepgen, 1951, p. 14).
}

respective sciences. The contributions of Reil to neuroanatomy have never been in doubt, and they have a magnificent monument in Neuburger's (1913) monograph on the occasion of the centenary of Reil's death. The anthropological research of Blumenbach, and the comparative and embryological work of Carus, Döllinger, and Baer have long been accepted, and even the significance of Treviranus, in the early history of the neurone, has been recently reassessed (Stieda, 1899; Clarke and O'Malley,1968). In contrast, it is remarkable how little has been written about the work of Burdach (see also Schmid, 1935) (Fig. 1). Neuburger (1897) certainly thought also of Burdach, when he tried to reassess the theories of the Naturphilosophen. The short biographical articles of Voit (1876, in German) and Bast (1923), though informative and instructive in some respects, fail to do justice to others. Of modern texts of medical history, only Mettler (1947) gives Burdach a column. Neither in the list of references nor in the index of the book of Clarke and O'Malley (1968) does the name of Karl Friedrich Burdach appear, and in Diepgen's (1951) history, Vom Baue und Leben des Gehirns is not contained in the relevant list of references. Only very recently, partial attempts have been made to reassess the situation (Meyer, 1966; Schiller, 1967).

VOM BAUE UND LEBEN DES GEHIRNS $(1819,1822,1826)$

I became more closely acquainted with the work of Burdach, and especially with his three volume work Vom Baue und Leben des Gehirns, when I was interested in Thomas Willis, of whose work Burdach had given the most penetrating account. I came to realize that it was not only Willis whom Burdach had singled out, but that the annotations (Anmerkungen) in the first two volumes of this work present an unrivalled source of historical information on macroscopic neuroanatomy. Poised, as it were, on the threshold of the neurohistological era, Burdach was able to survey the macroscopic era of neuroanatomy as a whole. In its comprehensiveness, accuracy, and dispassionate impartiality, the historical review of Burdach surpasses the earlier works of Portal (1770-73), Haller (1774-77), and the 


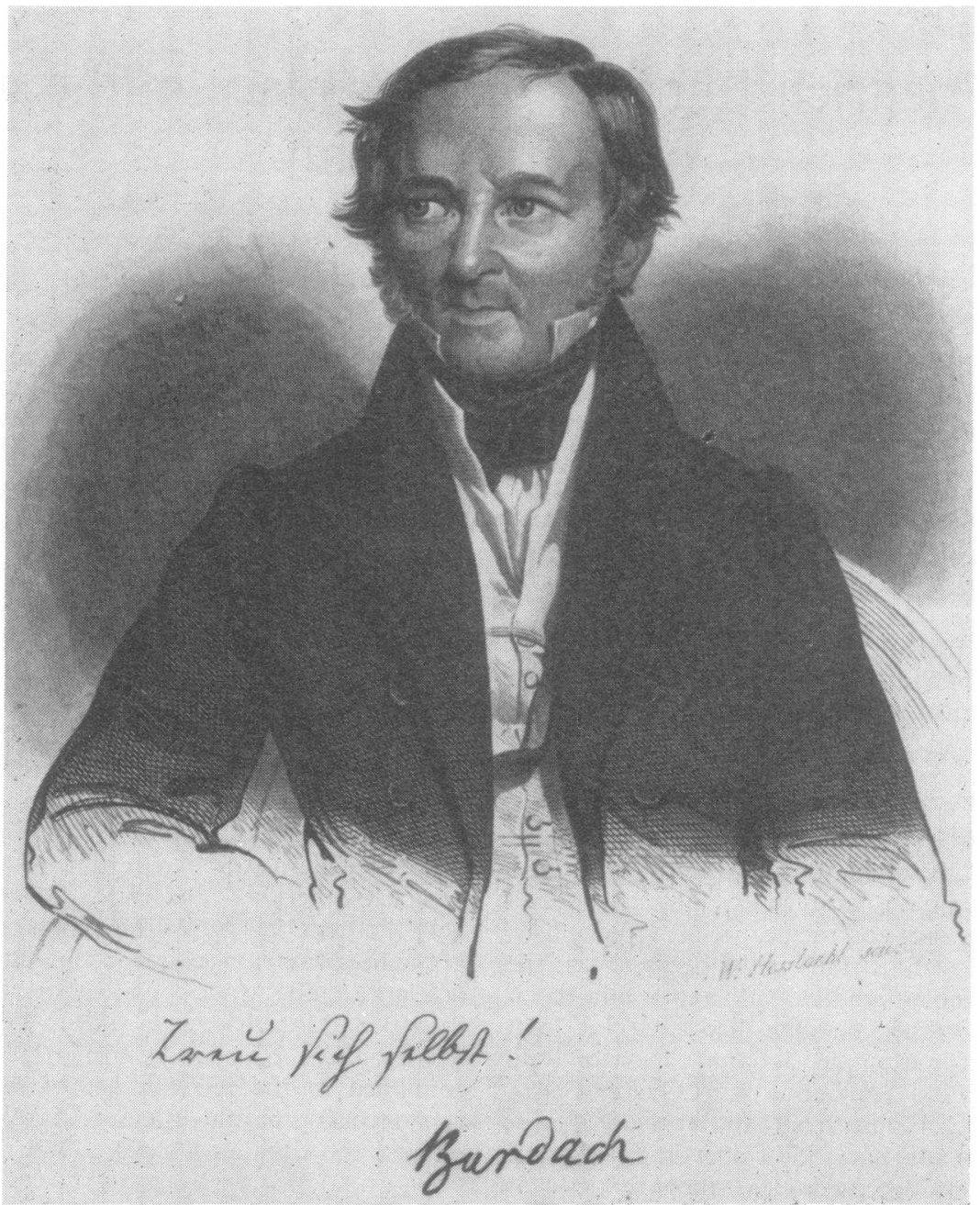

FIG. 1. Portrait of Burdach from Anthropology (1847).

historical information contained in texts such as, for example, those of Vicq d'Azyr (1786), Sömmerring (1798), and Charles Bell (1802).

I shall not deal here at length with Burdach as a historian: this has been done in the earlier paper of 1966. It is surprising how little this important aspect of Burdach's work is now known. Arnold (1838), Stilling (1857/9), and Forel (1877) knew of it, and made no secret of how much they relied on Burdach's historical account. Edinger (1904) spoke with appreciation of Vom Baue und Leben des Gehirns as 'a landmark which faithfully recorded all previous work and added much that was new and clarifying'. However, I have been at a loss to find any mention of it in the biographical assessments of Voit (1876) and Bast (1923) or in the medical histories of Mettler (1947) and Diepgen (1951). Only Schiller (1967) spoke recently of Burdach's book as ano 'unmatched' source of historical information on $\frac{\text { 을 }}{3}$ neuroanatomy.

Vom Baue und Leben des Gehirns is alive today150 years after the publication of the first volume-2 also in other respects. Every student knows of Burdach's column, the tractus cuneatus. Burdach $\triangle$ also knew what we now incorrectly name the을 fasciculus gracilis of Goll (1860). As Burdach points out, it was already illustrated by Santorini (1775, Table 3, Fig. 2) and described by Reil (1809), who N 
named it 'Zarter Strang'-Goll's fasciculus gracilis is thus only a translation of Reil's term.

\section{ANATOMICAL NOMENCLATURE OF BURDACH}

Relatively few are now aware of the range of names which Burdach introduced, and which have found a permanent place in anatomical nomenclature. It was he who, in 1800 , in a footnote to p. 62 of his Propädeutik zum Studium der gesammten Heilkunde (Introduction to the Study of Medicine) introduced the general terms 'biology' and 'morphology' (Schmid, 1935) ${ }^{1}$. Biologie had for Burdach approximately the same meaning as it has for us today. Its origin is usually (but wrongly) attributed to G. R. Treviranus who used it as title for his book (1802-1822), and to J. B. Lamarck (1802). Of morphology Burdach wrote in $1806^{2}$ and 1814 , and in 1817 he expatiated 'On the task of morphology' on the occasion of the opening of the Anatomical Institute at Königsberg. Shortly before this, Goethe had begun to publish independently his Hefte zur Morphologie which were to appear between 1817 and 1824. Goethe's authority was so great that the term became affixed to his name rather than to that of Burdach. If there should be still any doubts, they are dispersed by Burdach himself who in his posthumous Autobiography $(1848$, p. 332$)$ said: 'I had used this term (Morphology)first in my 'Propädeutik' of 1800 , then in my Beiträge zur näheren Kenntnis des Gehirns, and also in my Anatomische Untersuchungen; it belongs, therefore, to me.' Both Goethe and Burdach used the term in the same sense. They understood it to denote a total view on life, in contrast to the partial impressions derived from sciences such as anatomy, zoology, physiology, and chemistry-that is, different from its present-day anatomical or structural meaning.

Burdach's new names for concrete structures of the nervous system are contained in Vom Baue und Leben des Gehirns. They include: lenticular nucleus, putamen, globus pallidus, claustrum, pulvinar, internal and external capsules (capsule was Reil's (1809) term), amygdaloid nucleus, red nucleus, lamina terminalis, pedunculus septi, pallium, cingular cortex, cingulum, longitudinal association tracts, subiculum, alveus, cuneus, and precuneus. Not all the structures he named were discovered by him. Nevertheless he gave the first description and illus-

\footnotetext{
${ }^{1}$ Burdach's work of 1800 was not available to me in the original. I have had to rely on the careful analysis of Schmid which was accepted by Strauss (in Grünthal and Strauss, 1949, p. 70), Diepgen (1951), and Baron (1966).

${ }^{2} 1806$ in Beiträge zur näheren Kenntniss des Gehirns (Leipzig), 1814 in Anatomische Untersuchungen bezogen auf Naturwissenschaft und Heilkunst, Leipzig, and 1817 in Uber die Aufgabe der Morphologie, Leipzig.
}

tration of the amygdaloid nucleus; with the name globus pallidus, he, as the first, demonstrated a characteristic difference-that is, the relative content of myelinated fibres-between the two members of the lenticular nucleus. The superior and inferior longitudinal association bundles are his discoveries. When, in 1896, Flechsig described the temporal knee or loop of the visual radiation, it was soon realized that this was identical with Burdach's inferior longitudinal bundle; thus Burdach should be given some recognition for the first, albeit unwitting, description of part of the visual radiation.

The tractus siliquae (Hülsenstrang) was another of Burdach's descriptions which made history: tractus siliquae internus and externus enclose the inferior olives, before they run down into the spinal cord. As Türck discovered in 1851, the internal component is identical with what we now know as uncrossed or ventral pyramidal tract. Türck accepted Burdach's description and himself continued to call the tract Hülsenvorderstrang.

Burdach did not discover the red nucleus, but he gave the first detailed description of it. As historian, he informed us, that Santorini (1775) had already provided an illustration (his Table 3, Fig. 3E) and that Vicq d'Azyr (1786, Tables 14 and 23) had seen it as tâche rougeatre 'in the depth of the thalamus'. Reil $(1809$, p. 512$)$ had also observed a 'spherical dot of grey matter, within the posterior aspect of the optic thalamus.... the substantia nigra goes through it ....'

Burdach divided the thalamus into four nuclei: an internal (our dorso-medial), superior (our anterior), external (our lateral), and a posterior (his pulvinar). He described, as the first, the lamina medullaris interna between internal and external nucleus, and a lamina cornea (probably our lamina medullaris external + reticular nucleus) outside the external nucleus. With these subdivisions, Burdach laid the foundation of modern thalamic classification. In 1872, Forel described it as 'almost perfect, and should be, therefore, retained or, rather, reinstated with honours.'

On the cerebral hemisphere, Burdach distinguished the pallium (mantle) from the 'nucleus' which comprehended subcortical grey matter. Both terms have come to stay, very much as Burdach conceived them (see also Schiller, 1967). The term 'nucleus' is now used alternatively with 'ganglion', a term introduced by Reil (1809) and Gall and Spurzheim (1810) to indicate well-defined central clusters of grey matter.

\section{BURDACH AS AN ILLUSTRATOR}

Burdach is not usually counted among the great 
illustrators of cerebral anatomy, but some of his illustrations are of considerable interest. He gave, for example, the first adequate illustration (his Table 36) of the insula, before Rolando (1831) who is often given credit for it. Burdach (1.c. 2, p. 167/8) spoke of a vordere Ecke (anterior corner) of the insula-an anticipation of the limen insulae described and named much later by Schwalbe(1881).

The most interesting illustration of Burdach is his diagram of Table 7 (reproduced in our Fig. 2): it presents the medial aspect of the hemisphere and shows $(\beta-\beta x)$ the posterior fissure (first described and named by Sömmerring, 1778), our parietooccipital. The cuneus lies between the posterior sulcus and what Burdach named die Furche unter dem Zwickel' (sulcus beneath the cuneus; $\delta-\beta \mathrm{x}$ ). This is, to my knowledge, the first description and the first name of our calcarine fissure, though not its first illustration; it had been indicated-not very clearly_in illustrations of Sömmerring (1778), Vicq d'Azyr (1786), and Gall and Spurzheim (1810). In 1831 (almost 10 years after Burdach), Rolando provided another good illustration, and, more important, he recognized the relationship of this sulcus with the calcar avis, lying in its depth.

Returning to Burdach's diagram, both posterior sulcus $(\beta-\beta x)$ and the one that lies beneath the cuneus $(\delta-\beta \mathrm{x})$ continue in an anterior direction $(\beta x-\gamma)$. This is the first clear illustration of what is now known as the hippocampal fissure. However, Burdach had no name for it; this was left to Gratiolet (1854, Fig. 3), whose diagram (our Fig. 3) impresses one as an improved edition of Burdach's. In this, Gratiolet showed the anterior continuation, and gave it its permanent name 'scissure des hippocampes' but he had no name for Burdach's 'sulcus beneath the cuneus' (B- $B_{1}$, in Gratiolet's diagram). HeD demonstrated it, however, as separate from the parieto-occipital sulcus (Gratiolet's 'fissure per: pendiculaire interne', A-A). It was T. H. Huxleyo (1861) who finally introduced the terms parietooccipital and calcarine. Huxley also demonstrate that calcarine and hippocampal fissures are not continuous.

The history of the calcarine fissure advanced yet another step when, in 1892, Cunningham, and later Elliot Smith $(1903,1904)$ divided it into an anterior: and a posterior (or retrocalcarine) part. What the modern Nomina Anatomica (1961) records asen calcarine fissure, corresponds to its posterior portion only-and this has no relation to the calcar avis The so-called true calcarine fissure (with the calcars avis in its depth) appears, in the Nomina Anatomica $\vec{P}$ as anterior calcarine or posterior splenial sulcus.

\section{THE FUNCTION OF THE BRAIN}

Many of Burdach's hypotheses on the function of the brain are now obsolete, but a few are still of interest. His theoretical thought was modelled frin Thomas Willis; this admiration for Willis, who was one of his 'Immortals', derived from a similarity? their general attitude to natural science. He appreciated in Willis what he was himself: a combinationo of the accurate and original observer with 'philosopher of nature', who built from concrete anatomical data an overall theory of nervous a mental function. Like Willis, Burdach considezecte the region of the midbrain, and especially the corpora quadrigemina, as a centre controlling viscera

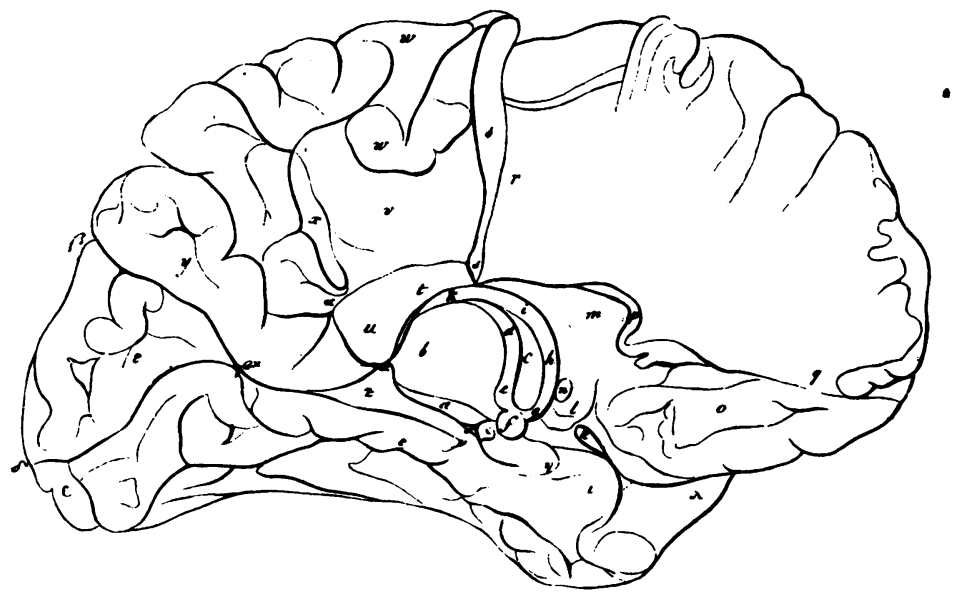

FIG. 2. From Burdach (1819-26, Table 7). Diagram of left human hemisphere, medial aspect, $\beta-\beta \mathrm{x}$, posterior (our parietooccipital) fissure; $\delta-\beta \mathrm{x}$ 'the sulcus beneath the cuneus'-that is, our calcarine fissure; $\beta \mathrm{x}-\gamma$, our hippocampal fissure. 


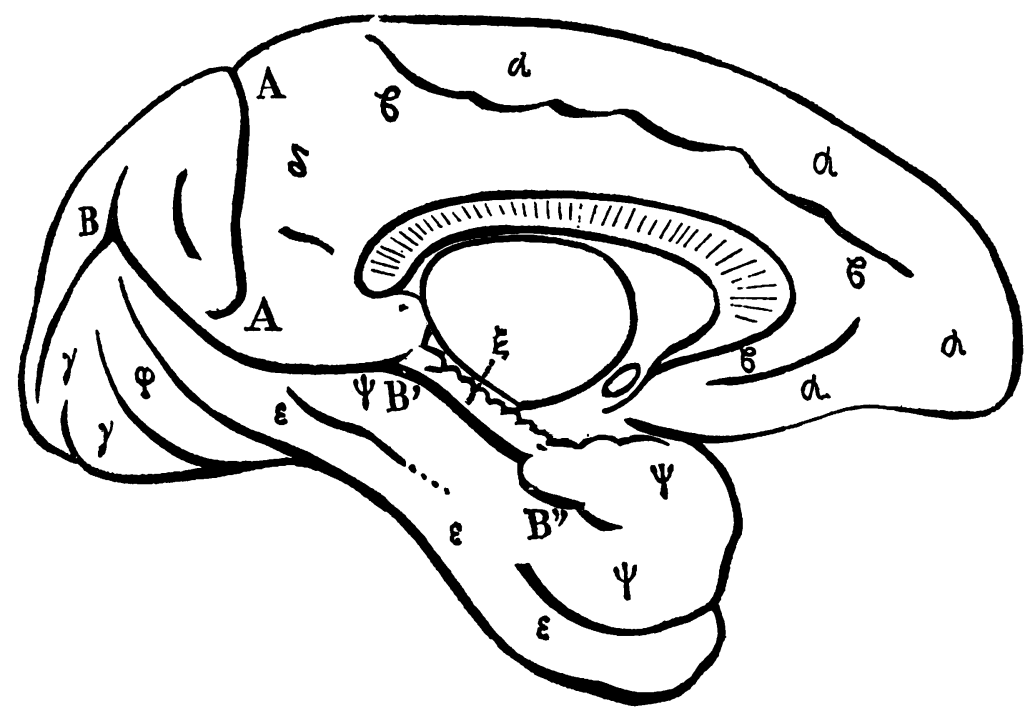

FIG. 3. From Gratiolet (1854, Fig. 3). Diagram of medial aspect of left hemisphere. $A-A=$ our parieto-occipital fissure. $B-B_{1}=$ our calcarine fissure. Its continuation $B_{1}-B_{2}=$ our hippocampal fissure. $B-B_{2}$ named 'fissures des hippocampes'.

activity, hunger, thirst, digestion, and other instinctual drives. The corpus striatum, he believed is related to motor action and will-a view which was still maintained by Hughlings Jackson in his early period and by Meynert in 1884 .

Fornix, cingulum, mammillary bodies, and Ammon's horn serve imagination. One has to remember that, in Burdach's times, these structures were not yet related to olfactory function. It is only in our time that the earlier views of their function have regained some of their original importance.

Burdach observed that the mammillary bodies atrophy following malformation or absence of the fornix - surely an early anticipation of modern views, established by the experimental work of Gudden in 1881 .

Burdach's views on thalamic function are still of interest: 'it is the root', he said, 'of consciousness which is further developed in the corona radiata and ultimately perfected in the covering organ'that is, chiefly cortical grey matter. The thalamus, he added, is the place of origin of most of the fibres of the corona radiata-one of the earliest visions of thalamo-cortical pathways!

Burdach's views on the frontal lobe are likewise of interest. On the one hand, since the frontal region is less developed in lower mammals, it is, he thought, concerned with intellectual function; on the other hand, its proximity to the olfactory bulb and tract points to an association with instinctual life and direction towards the future. For, he said, 'the sense of smell is a plant-like, passive and subjective sensation ... in contrast to other senses, it is turned towards the future.' In our time, Freeman and Watts (1942) argued differently, but they too arrived at the same conclusion: that the frontal lobe is concerned with consciousness of the self and its projection into the future.

\section{OTHER WRITINGS OF BURDACH}

Burdach himself considered Vom Baue und Leben as his chef-d'oeuvre on neuroanatomy $(1848$, Autobiography, p. 298). It is, therefore, the main source for the purposes of this paper. The picture of the man and his work would be incomplete, however, if no consideration were given to his numerous other writings. Their number is large. (Bast listed 48 items, most of them volumes of considerable length.) The wide span of his interests is equally impressive.

He wrote on Anatomy and Neuroanatomy in 1806, 1814, and 1817; these three publications have already been mentioned in relation to the term morphology. In 1818 , he described the 'texture of the cauda equina', followed in 1820 by remarks on cardiac valves: these last two publications are especially mentioned by Burdach (Autobiography, 1848, p. 532) among the results of his original research which he valued most.

On pathology, Burdach wrote only once (1808)-a Handbuch of over 400 pages. Pharmacy was treated in a four-volume work in 1807 to 1809 , a second edition, in four volumes (pp. 278, 564, 572, 423 respectively), appeared in 1817 to 1819 . General medicine was the subject of a 'Propaedeutik' (Introduction) in 1800 (when he first spoke of biology and morphology). Later, 1810 to 1816 , he published an 'Encyclopaedia of Medicine', in three volumes (pp. 634, 746, 368 respectively).

I have left his writings on physiology (and related disciplines) as the last item because this subject occupied him chiefly in the last phase of his life, after he had completed Vom Baue und Leben des Gehirns. He had already 
written Die Physiologie in 1810, but his main work on the subject Physiologie als Erfahrungswissenschaft ('Physiology as an Experiential Science') appeared in six volumes (some of them in two editions) between 1826 to 1840. In these volumes Burdach collaborated with a number of outstanding workers: Karl Ernst von Baer, Heinrich Rathke, E. H. F. Meyer, Johannes Müller, Rudolph Wagner, Gabriel Gustav Valentin, Karl Theodor von Siebold, A. Hayn, L. Moser, J. F. Dieffenbach, and his son, Ernst Burdach. Burdach himself contributed to all volumes.

It was especially the higher human functions which had to be omitted in the 'Physiology as an Experiential Science'. Much of Burdach's subsequent work was intended to fill this gap: this applies, for example, to his Anthropology of 1837, which, at the request of the publishers, appeared in a (posthumous) second edition in 1847, edited by Ernst Burdach. It contains the portrait of Karl Friedrich which has been reproduced for this paper. Likewise, Burdach's Blicke ins Leben (Views on Life, 1842-1848, in four volumes), to some extent served the same purpose: the first two volumes (1842) contain a Comparative Psychology. The third volume (1844) is entitled Sinnesmängel und Geistesmacht (Limits of the Senses and Power of the Mind). In the same year (1844), Burdach published a small monograph (76 p.) of Umrisse einer Physiologie des Nervensystems (Outline of a Physiology of the Nervous System).

The fourth volume of Blicke ins Leben presents an Autobiography (Selbstbiographie) of 603 pages. It was left in an uneven state of completion at his death and was edited, in 1848, by Ernst Burdach.

Today these books are forgotten-apart, perhaps, from the Physiology as an Experiential Science and the Autobiography which are occasionally mentioned by historians. In Burdach's life-time this was not so. As we know from many sources, Burdach had a reputation as an excellent lecturer. Many of his books, particularly the earlier ones, owed their origin to lectures, and public demand was such that often second editions became necessary. Bischoff (1841, p. II) reviewing in Müller's Archiv the last volume of Physiology as an Experiential Science spoke of 'this comprehensive and magnificently conceived work which unfortunately will now remain incomplete.' Voit (1876), like some others, believed that Physiology as Experiential Science was the most important of all publications of Burdach. ${ }^{1}$

Both Voit and Bast believed that all these voluminous books became obsolete because they are barren of concrete discoveries by Burdach. This view is probably true. Burdach himself, in his Autobiography, listed only a few minor concrete contributions by himself to physiology. Important discoveries were reported by many of Burdach's out-

${ }^{1}$ Karl von Voit, famous for his contributions to the chemistry of nutrition, was, as far as I could ascertain, not a medical man. Likewise Bast, who was influenced by Voit, signed himself as a Ph.D. standing collaborators (Johannes Müller, Karl Ernst v. Baer, for example), in separate sections of their own or incorporated under their name into the general text by Burdach; but these had been previously or at the same time reported elsewhere. ${ }^{1}$ No wonder, then, that a new generation of outstanding workers turned, with almost unprecedented enthusiasm, to new and refined methods of dissection, and replaced Bichat's theoretical concept of tissues (which was according to Baer (1865) the basis of Burdach's teaching and writing of anatomy) by concrete histological investigation. These younger workers turned to Johannes Müller's Handbuch which was full of original discoveries, to the experimental investigations of Magendie (from 1822 onwards, vide Magendie, 1823) and to Bell's (1811) demonstration of the functional difference between anterior and posterior roots, confirmed by Müller in 1831. ${ }^{2}$ Burdach's Physiology as an Experiential Science has been likened by Boruttau (1903) to Haller's Elementa physiologiae (1757-66), but Dubois-Reymond (1860) was probably more to the point, when he compared Müller's Handbuch with Haller's classical work. Although Müller's book of (he himself called it a lumber room (Rumpelkammer) could not bear comparison with the classical event ness and painstaking care with which Haller treate ${ }_{0}$ his material, they both had a profound influence of their respective generations.

Burdach, erudite and well informed about the newest developments though he was, did not under stand the profound significance of what was hapipening. In his Autobiography (1848, p. 532 et seq he spoke of the 'indefatigable Johannes Müller, who lost himself in isolated materialistic theories, despite his wealth of observations and his philosophical refinement.' On the occasion of a visit to Paris in 1826, he met Magendie (1848, p. 382) who

${ }^{1}$ This arrangement resulted in an unpleasant encounter with Baer in 1828, who resented arbitrary alterations of his contribution by Burdach and, in general, was not content to confine himself to an 음 'opusculum in opere'. Without informing Burdach, Baer published in $\bar{\exists}$ the same year the first volume of his Developmental History of Animals. Both men took this incident seriously, as is indicated by extensive discussion in their respective autobiographies (Burdach, 1848, pp. 378-379; Baer, 1866, pp. 303-305; 334-343). Probably both men were to blame for this termination of a long friendship: Baer because of his understandable, but tactless behaviour, and Burdach because of $\overline{0}$ an over-sensitivity which he himself recorded in his autobiography. $\bar{\sigma}$ No similar dissensions are known between Burdach and his numerous collaborators: Stilling (1857-9) spoke of the 'noble Burdach'.

Johannes Müller's contributions to Physiology as an Experiential Science were almost simultaneously published (1832) in the first volume of his Handbuch der Physiologie des Menschen.

In 1840, after appearance of the second volume, Müller abandoned his Handbuch and physiological work. Koller (1958, p. 136), a recent I biographer, suggests, as one of the reasons, that Müller felt further 을 progress would be in the hands of chemists and physicists; he returned, for the rest of his life, to comparative anatomy. A depression with o which Müller was afflicted in 1840 and his abhorrence of vivisection are among other reasons which have been proffered to explain his $\mathrm{N}$ abandonment of physiological work.

(1)

.


acquainted Burdach with his newest experiments (on the cerebellum and corpus striatum), which he demonstrated to his visitor. Burdach admired the unusual dexterity and competence with which Magendie manipulated the experiments, but as a whole, he confessed, the visit to Magendie was 'incomparably less to his liking than that to others in Paris, for example Cuvier and Blainville'.

In volume 5 (1835) of Physiology as an Experiential Science, Burdach and Rudolf Wagner gave only a brief account (of 10 pages) of the nervous system, which is more or less confined to nerve fibres, and mentions only granules (Körnchen) and globules (Kugeln). The discovery of the nerve cell by Ehrenberg in 1833 is not mentioned. Perhaps, it was then too early to expect more on the newly discovered nerve cells and their relation to nerve fibres. But even much later, in his Autobiography (p. 539 et seq.) Burdach said only that he regarded the publications of 'Purkinje and Valentin with utmost interest'; there is no indication that he really comprehended the revolutionary significance of the work of these workers and of others whom he did not mention.

\section{BURDACH AS EMPIRICAL SCIENTIST}

While all this tends to demonstrate that the judgment of Voit (and Bast) was correct, I cannot agree with the second part of Voit's statement that 'all Burdach's writings were excellent, but they showed a futile endeavour to consider all phenomena in the light of nature philosophy and general points of view'. I am unable to judge of Burdach's earlier books which were not accessible to me, but I have read his volumes after Vom Baue und Leben des Gehirns. In fact, there is very little 'philosophy of nature' in the sense of Schelling in any of these; what there is, is confined to a few sentences usually in the introduction and in the closing pages. On many occasions, Burdach expressly excluded philosophy from a text which should be reserved to orderly description of observations gained from experience. In Physiology as an Experiential Science (vol. 1, p. 5) he said: 'We begin, therefore, with the examination of single, real facts, but in a manner that we always try to contemplate related manifestations in their common concepts and specific peculiarities ...' He was even more explicit in the introduction to his later Comparative Psychology of 1842 (p. IV): 'The treatment of mental events will be conducted as a real experiential science, in the same way, as the science of nature-as it is seen in life, and without alien intrusion of pious extravagancies or of barren speculations.' In his Autobiography he, again, defended himself against the accusation of indulging in Schellingian philosophizing: 'I have familiarised myself with the doctrines of Kant, Fichte, Schelling and Hegel, but I was unable to follow any of these into the depth of speculation, least of all Hegel. . . . That the Naturphilosophen would reject me as a mere empirical scientist, I have already mentioned earlier; notwithstanding their disapproval, I continued in my task to enrich knowledge . ...'

Schmid (1935) came to the general conclusion that of the 'nature philosophers' Burdach was the most empirical. This is also my own conclusion after studying almost all his works from Vom Baue und Leben des Gehirns $(1819 / 26)$ onwards.

In Burdach's later mature writings, one idea is frequently met: the importance of comparative behaviour studies. This idea (he included it among the 'fixed ideas' in his autobiography, p. 383) had occupied him since 1814, but it was first formulated in a paper on 'Psychology as-a natural science', given to the society of physicians and natural scientists, meeting in 1828, at Berlin. He tried to show that, just as physiology had flourished only by investigating it in all its comparative aspects, so psychology should go the same way and should extend to behaviour studies at all levels of animal development. This suggestion strongly impressed the meeting, and we find it expounded at length in most of his later work. Burdach himself did not claim originality for this idea because comparative behaviour studies had already been carried out in France and Britain, but he was probably the first to suggest such investigations in Germany.

\section{HISTORICAL VALUE}

Burdach's later writings are not only encyclopaedic textbooks: they are historical documents. Neither Voit nor Bast recognized in Burdach's tendency to systematize his historical propensity, which had already come to such magnificent fruition in Vom Baue und Leben des Gehirns. Perhaps these worksespecially the Physiology as an Experiential Science, the Comparative Psychology, and the Autobiography -will be rescued from oblivion, and may be treated as important historical sources of both their subjects and of the contemporary scene.

Burdach's strong historical bent may have been partially responsible for his lack of understanding of the aims and achievements of the younger generation (some of them his own associates), which certainly was a serious shortcoming in his stature as a scientist and teacher.

In the course of this paper, I have frequently referred to the Autobiography of 1848. This is a remarkable document for several reasons. It was the first full-fledged autobiography of a neuroanatomist and, secondly, it is noteworthy because of the 
candour and modesty with which he discussed his own personality, assets as well as failures. His brief and unadorned account of his own neuroanatomical contributions and his frankness about his limitations may well have biased the judgment of both his biographers.

\section{CONCLUSIONS AND SUMMARY}

I hope I have been able to demonstrate that the concrete contributions made by Burdach to neuroanatomy were far more substantial and enduring than is generally recognized. Voit and Bast, his biographers, who relied on Burdach's own modest account, did not do him full justice. Bast considered Burdach was no genius, that he had many interests, but was master of none. This, in my opinion, is only part of the truth: Burdach was a master of neuroanatomy, to which he not only made many concrete contributions but of which he also gave a masterly history. He was, however, no iconoclast in neuroanatomy; this he had to leave to a younger generation, in particular to Johannes Müller and his school, Magendie and others, whose work Burdach grossly underestimated.

I am grateful to the Trustees of the British Museum for their permission to reproduce the portrait of Burdach, and to the staff at the libraries of both the Royal Society of Medicine and the British Museum for their general assistance and courtesy. I am also greatly indebted to my wife, Dr. Nina Meyer, who improved style and precision of the manúscript, and to Mrs. Ursula Baker for her secretarial services.

\section{REFERENCES}

Arnold, F. (1838). Bemerkungen über den Bau des Gehirns und Rückenmarks. Höhr: Zürich.

Baer, K. E. von (1828). Uber Entwicklungsgeschichte der Thiere. Vol. 1. Bornträger: Königsberg.

Baer, K. E. von (1865). Nachrichten über Leben und Schriften des Herrn Geheimrats... Mitgeteilt von ihm selbst. $\mathrm{K}$. Hofbuchhdl. Schmertzdorf: St. Petersburg.

Baron, W. (1966). Gedanken über den ursprünglichen Sinn der Ausdrücke Botanik, Zoologie und Biologie. In: Medizingeschichte im Spektrum Festschrift of J. Steudel. Sudhoff's Arch., Beiheft 7, 1-10.

Bast, T. H. (1923). Karl Fredrick Burdach. Ann. med. Hist., 10, 34-46.

Bell,C.(1802). The Anatomy of the Brain, Explained in a Series of Engravings. Longmans: London.

Bell, C. (1811). Idea of a New Anatomy of the Brain submitted for the Observations of his Friends. Strahan and Preston: London.

Bischoff, Th. L. W. (1841). Bericht über die Fortschritte der Physiologie im Jahre 1840. Edited by J. Müller, pp. ILXVIII. Arch. Anat. Physiol.

Boruttau, H. (1903). Geschichte der Physiologie in ihrer Anwendung auf die Medizin bis zum Ende des neunzehnten
Jahrhunderts. In: T. Puschmann's Handbuch der Geschicht $Z$ der Medizin, edited by M. Neuburger and J. Pagel, vol. 2: pp. 327-456. Fischer: Jena.

Burdach, K. F. (1800). Propädeutik zum Studium der gesamter Heilkunde. Breitkopf und Härtel: Leipzig.

Burdach, K. F. (1806). Beiträge zur näheren Kenntnis des Gehirns ... 1. Teil. Breitkopf und Härtel: Leipzig.

Burdach, K. F. (1808). Handbuch der Pathologie. Voss Leipzig.

Burdach, K. F. (1810). Physiologie. Weidmann: Leipzig.

Burdach, K. F. (1810-12). Encyklopädie der Heilwissenschaft 3 vols. Mitzky: Leipzig.

Burdach, K. F. (1814). Anatomische Untersuchungen bezogen auf Naturwissenschaft und Heilkunst. Mitzky: Leipzig.

Burdach, K. F. (1817). Über die Aufgabe der Morphologie Dyk'sche Buchhdl: Leipzig.

Burdach, K. F. (1817-19). System der Arzneimittellehre (2nd edit.), 4 vols. Dyk'sche Buchhdl: Leipzig.

Burdach, K. F. (1819-26). Vom Baue und Leben des Gehirns 3 vols. Dyk'sche Buchhdl: Leipzig.

Burdach, K. F. (1826-40). Die Physiologie als Erfahrungs $-\overrightarrow{-}$ wissenschaft. 6 vols. Voss: Leipzig.

Burdach, K. F. (1837). Anthropologie für das gebildetePublikum. (2nd edit. 1847). Balz'sche Buchhdl: Stuttgart.

Burdach, K. F. (1842). Comparative Psychologie. In: Blicke ins Leben (1842-1848). Volumes 1-2. Voss: Leipzig.

Burdach, K. F. Selbstbiographie. In: Blicke ins Leben (18421848). Vol. 4. Voss: Leipzig (edited posthumously by $E_{\cdot \omega}^{\omega}$ Burdach).

Clarke, E., and O'Malley, C. D. (1968). The Human BrZitio and Spinal Cord. University of California Press: BerkeRy. and Los Angeles.

Cunningham, D. J. (1892). Contribution to the Surfes Anatomy of the Cerebral Hemispheres. Royal AcadefyHouse, Dublin.

Diepgen, P. (1951). Geschichte der Medizin, Vol. 2, part de Gruyter: Berlin.

Dubois-Reymond, E. (1860). Gedächtnisrede auf Johanties Müller. Akad. Wissensch: Berlin.

Edinger, L. (1904). Vorlesungen über den Bau der nervösen $\overrightarrow{0}$ Zentralorgane des Menschen und der Thiere. Vogel: Leipzïg.O

Ehrenberg, C. G. (1833). Nothwendigkeit einer feineren mechanischen Zerlegung des Gehirns und der Nerven. Poggend. Ann. Phys., 28, 449-473.

Flechsig, P. E. (1896). Weitere Mittneilungen über den Stabkranz des menschlichen Grosshirns. Neurol. Cbl., 15, 2-4.

Forel, A. (1872). Beiträge zur Kenntnis des Thalamus@ opticus und der ihn umgebenden Gebilde bei den Säugetieren. In: Gesammelte hirnanatomische Abhandlungen, pp. 18-43. Reinhardt: Munich. 1907.

Forel, A. (1877). Untersuchungen über die Haubenregion. Arch. Psychiat. Nervenkr., 7, 393-495.

Freeman, W. J., and Watts, J. W. (1942). Psychosurgery. Blackwell Scientific Publications: Oxford.

Gall, F. J., and Spurzheim, C. (1810). Anatomie et physiologie. du systeme nerveux (with separate volume of illustrations). Schoell: Paris.

Goll, F. (1860). Beiträge zur feineren Anatomie des mensch-i lichen Rückenmarks. Denkschr. Med. Chir. Gesellsch.을 (Zürich).

Gratiolet, M. P. (1854). Mémoire sur les plis cérébraux de음 l'homme et des primates. Bertrand: Paris.

Grünthal, E., and Strauss, F. (1949). Abhandlungen zu Goethes Naturwissenschaft. Haupt: Bern.

Gudden, B. A. von (1881). Beitrag zur Kenntnis des CorpusN mammillare und der sogenannten Schenkel des Fornix. Arch. Psychiat. Nervenkr., 11, 428-452.

Haller, A. von (1757-1766). Elementa physiologiae corporis humani. 8 vols. Lausanne. 
Haller, A. von (1774-1777). Bibliotheca Anatomica. Orell, Gessner, Fuessli et Soc.: Zürich.

Huxley, T. H. (1861). On the brain of Ateles Paniscus. Proc. Zool. Soc., 247-260.

Koller, G. (1958). Das Leben des Biologen Johannes Müller 1801-1858, Wissensch. Verlagsgesellsch: Stuttgart.

Lamarck, J. B. (1802). Recherches sur l'organisation des corps vivants. (quoted from Schmid, 1935).

Magendie, F. (1823). On the functions of the corpora striata and corpora quadrigemina. Lancet, 1, 343-345.

Mettler, C. C. (1947). History of Medicine. Edited by F. A. Mettler. Blakiston: Philadelphia.

Meyer, A. (1966). Karl Friedrich Burdach on Thomas W'illis. J. neurol. Sci., 3, 109-116.

Meynert, Th. (1884). Psychiatrie, Klinik der Erkrankungen des Vorderhirns. Braumüller: Vienna.

Müller, J. (1831). Bestätigung des Bell'schen Lehrsatzes . . durch neue und entscheidende Experimente. Frorieps Notizen, 30, 113-117.

Müller, J. (1832-1840). Handbuch der Physiologie des Menschen für Vorlesungen. 2 vols. J. Hölscher: Coblenz.

Neuburger, M. (1897). Die historische Entwicklung der experimentellen Gehirn- und Rückenmarksentwicklung. Enke: Stuttgart.

Neuburger, M. (1913). Johann Christian Reil. Enke: Stuttgart.

Nomina Anatomica (1961). 2nd edition. Excerpta Medica Foundation: Amsterdam.

Portal, A. (1770-1773). Histoire del'anatomie et de la chirurgie. P. F. Didot le jeune: Paris.

Reil, J. Chr. (1809). Das verlängerte Rückenmark, die hinteren, seitlichen und vorderen Schenkel des kleinen Gehirns und die theils strangförmig, theils als Ganglienkette in der Axe des Rückenmarks und des Gehirns fortlaufende graue Substanz. Arch. Physiol. (Halle)., 9, 485-524.

Rolando, L. (1831). Della struttura degli emisferi cerebrali. Mem. Real. Accad. Scienze. Turin, 35, 103-146.

Santorini, G. D. (1775). Tabulae Anatomicae, edited by M. Girardi. Parma.

Schiller, F. (1967). The vicissitudes of the basal ganglia.
(Further landmarks in cerebral nomenclature.) Bull. Hist. Med., 41, 515-538.

Schmid, G. (1935). Über die Herkunft der Ausdrücke Morphologie und Biologie. Nova Acta Leopoldina (Halle). New series, 2, 597-620.

Schwalbe, G. (1881). Lehrbuch der Neurologie. In: Hoffmann's Lehrbuch der Anatomie des Menschen., Vol. 2. Erlangen.

Singer, Ch. (1959). History of Biology. Abelard-Schuman: London.

Smith, G. E. (1903). On the morphology of the brain in the mammalia, with special reference to that of the lemurs, recent and extinct. Trans. Linn. Soc. Lond. (Zool.), 2nd series, 8, 319-432.

Smith, G. E. (1904). The morphology of the occipital region of the cerebral hemispheres in man and the apes. Anat. Anz., 24, 436-451.

Sömmerring, S. T. (1778). De basi encephali et originibus nervorum cranio egredientium. Vandenhoeck: Göttingen.

Sömmerring, S. T. (1798). De corporis humani fabrica, vol. 4: De cerebro et de nervis. Varrentrapp und Wenner: Frankfurt am Main.

Stieda, L. (1899). Geschichte der Entwicklung der Lehre von den Zellen und Nervenfasern während des 19. Jahrhunđert. In: Festschrift zum siebenzigsten Geburstag von $C$. von Kupffer, 1, 79-196. Fischer: Jena.

Stilling, B. (1857-1859). Neue Untersuchungen über den Bau des Rückenmarks. Hotop: Cassel.

Treviranus, G. R. (1802-1822). Biologie oder Philosophie der lebenden Natur für Naturforscher und Ärzte. Röwer: Göttingen.

Türck, L. (1851). Über sekundäre Erkrankung einzelner Rückenmarksstränge und ihrer Fortsetzungen zum Gehirn. Gesammelte neurologische Schriften. Jb. Psychiat. Neurol., 1910, 31, 64-85.

Vicq d'Azyr, F. (1786). Traité d'anatomie et de physiologie. F. A. Didot l'ainé: Paris.

Voit, K. von (1876). Burdach, Karl Friedrich. In: Allgemeine Deutsch. Biograph. vol. 3, 578-580. 